\title{
Suitability Analysis of the Potential Gas Fields of Bangladesh for Carbon Dioxide Sequestration and A Simulation Approach for Titas Gas Field
}

\author{
S. M. S. Hoque ${ }^{1 *}$, M. A. Iqbal ${ }^{1}$, S. I. Ahmed ${ }^{1}$, M. A. Islam ${ }^{2}$ \\ ${ }^{1}$ Department of Petroleum \& Mining Engineering, Chittagong University of Engineering \& \\ Technology, Bangladesh \\ ${ }^{2}$ Department of Petroleum and Mining Engineering, Military Institute of Science and Technology, \\ Bangladesh
}

Received 2 August 2018, accepted in final revised form 3 December 2018

\begin{abstract}
Global warming has become one of the major environmental issues all over the world. The temperature of the world is increasing day by day, and fortunately, everybody wants to mitigate this fearful condition from own perspective. Carbon dioxide sequestration is a worldwide recognized project for making huge amount of carbon inactive, which is the main component of greenhouse gases, by sequestrating it beneath the Earth. The paper aims to dictate the probable success of $\mathrm{CO}_{2}$ sequestration in Bangladesh. As abandoned gas fields are the best options for sequestration, characteristics of the potential gas fields of Bangladesh have been analyzed according to Stefan Bachu's method of classification for $\mathrm{CO}_{2}$ sequestration. Titas gas field shows the best suitability, and accordingly, an Eclipse simulation software basis approach has been taken for this field to determine possible outcomes from probable sequestration project. Simulation result predicts an amount of 2.92 Tcf carbon dioxide gas to be sequestrated after 50 years of simulation. Other criteria such as field pressure, gas saturation are also evaluated.
\end{abstract}

Keywords: Bangladesh; $\mathrm{CO}_{2}$ Sequestration; Eclipse simulation; Gas fields ranking; Stefan Bachu classification.

(C) 2019 JSR Publications. ISSN: 2070-0237 (Print); 2070-0245 (Online). All rights reserved. doi: http://dx.doi.org/10.3329/jsr.v11i1.37756

J. Sci. Res. 11 (1), 41-63 (2019)

\section{Introduction}

Vast majority of scientists agree that global climate change is occurring and that to prevent it's most serious effects we must begin immediately to significantly reduce our greenhouse gas (GHG) emissions. One major contributor to climate change is the release of the greenhouse gas carbon dioxide $\left(\mathrm{CO}_{2}\right)$. As a developing country, carbon dioxide emission rate is explicitly escalating at a very high rate in Bangladesh. The GDP growth rate of Bangladesh increases from $6.5 \%$ to $7.1 \%$ from the year of 2012 to 2016 (World

\footnotetext{
*Corresponding author: czar0029@gmail.com
} 
Bank, 2016) and according to Alam [1], for the growing GDP of Bangladesh, industry and service sectors play a vital role which are also responsible for increasing $\mathrm{CO}_{2}$ emissions. Also, Bangladesh's remarkable economic growth is due to high cost of natural resources and health of the environment [2].

Gunter and Rahman [2] have worked together with a vision to provide an alternative projection for Bangladesh's future $\mathrm{CO}_{2}$ emissions to assess if Bangladesh is likely to achieve 'simple per capita income limit' that would be consistent with the Copenhagen accord by using data for the period of 1972-2005, and their findings are quite important. They have reached to a decision that $\mathrm{CO}_{2}$ emissions in Bangladesh will be 15 times larger in 2050 than 2005 if there is no improvement in country's energy efficiency. They finally concluded that as poverty reduction is imperative, some increases of $\mathrm{CO}_{2}$ emissions are unavoidable in Bangladesh and therefore, it is important to minimize this increase as far as possible by providing appropriate technologies [3].

$\mathrm{CO}_{2}$ emission as a whole and emission rate (metric tons per capita) of Bangladesh from the year of 1994 to 2014 are shown in Fig. 1. Both graphs showing an increase of $\mathrm{CO}_{2}$ emission.

Bangladesh produces a very small amount of global $\mathrm{CO}_{2}$ emission. But, the country's emission scenario has marked a rapid increase of $\mathrm{CO}_{2}$ emission over a long time. The overall $\mathrm{CO}_{2}$ emission has been increased to approximately $286 \%$ from the year 1994 to 2014 as shown in Fig. 1.

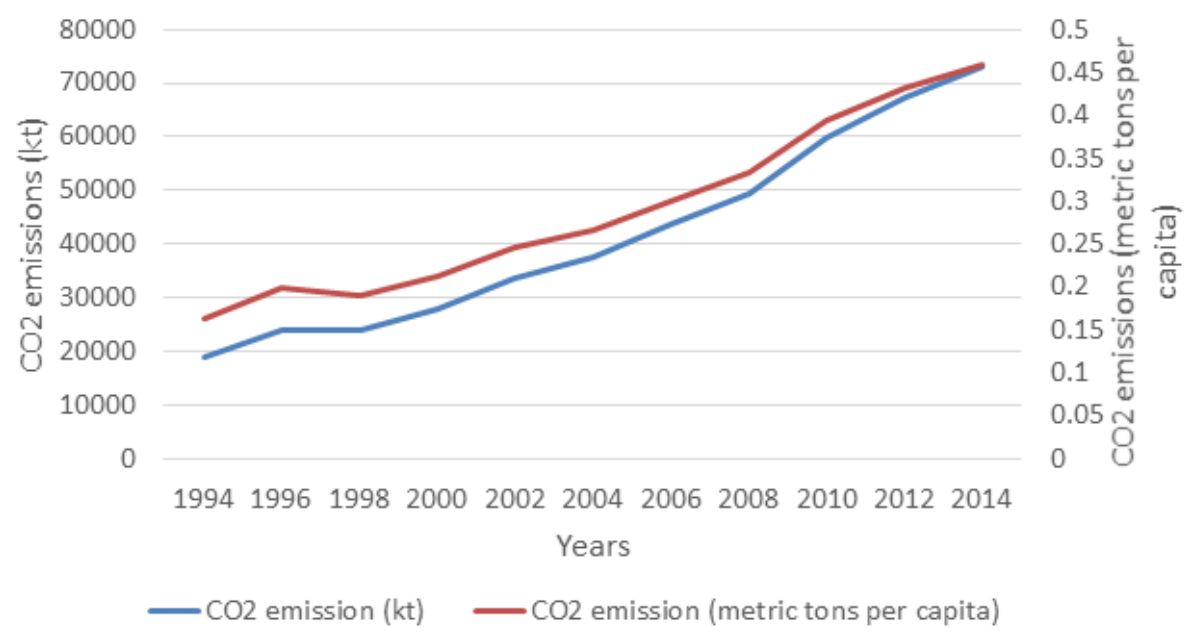

Fig. 1. Overall $\mathrm{CO}_{2}$ emission and $\mathrm{CO}_{2}$ emission rate (per capita) of Bangladesh (World Bank, 2015).

Evidently, Bangladesh is trying to implement a lot of initiatives and certain projects to decrease the emission rate and tackling climate changing impacts. Bangladesh has developed climate change strategy and action plan towards mitigation and low carbon development along with other strategic areas [4]. Eventually, with feasible economic planning, Bangladesh has a chance to develop a long term plan for $\mathrm{CO}_{2}$ sequestration in 
suitable place. Carbon or $\mathrm{CO}_{2}$ sequestration means putting carbon into long-term storage. It denotes the removal of $\mathrm{CO}_{2}$, either directly from anthropogenic sources, or from the atmosphere, and disposing of it either permanently or for geologically-significant time periods [5]. $\mathrm{CO}_{2}$ can be sequestered in deep underground formations of porous rock at least 2,500 feet below ground surface, but diligent geological site characterization is essential. To be suitable for CCS (Carbon Capture \& Storage), porous formations must lie under layers of impermeable rock that will provide a "cap" or seal to prevent upward migration of the $\mathrm{CO}_{2}$. Carbon dioxide can be sequestered in geological media by geological (stratigraphic and structural) trapping in depleted oil and gas reservoirs, solubility trapping in reservoir oil and formation water, adsorption trapping in uneconomic coal beds, cavern trapping in salt structures, and by mineral immobilization [6]. These media have both the space (porosity) and injectivity (permeability) necessary for $\mathrm{CO}_{2}$ injection, and, by and large, have the ability to either prevent or delay for geologically significant periods of time the $\mathrm{CO}_{2}$ return to the atmosphere. Crystalline and metamorphic rocks, such as granite, on continental shields are not suitable for $\mathrm{CO}_{2}$ storage and sequestration because they lack the porosity and permeability needed for $\mathrm{CO}_{2}$ injection, and because of their fractured nature. Volcanic areas and orogenic belts (mountains) are also unsuitable mainly because they lack capacity and are unsafe. Carbon dioxide sequestration in gas or oil field is far more attractive than other processes. The possibility of geological sequestration of carbon dioxide in Bangladesh is analyzed in this study. A series of suitability criteria for geological sequestration of $\mathrm{CO}_{2}$ were previously developed [6], they are:

- Basin characteristics, such as tectonism, geology and geothermal and hydrodynamic regimes (these are "hard" criteria because they do not change).

- Basin resources (hydrocarbons, coal, salt), maturity and infrastructure (these "semihard" or "semi-soft" criteria because they may change with new discoveries, technological advances and/or economic development).

- Societal, such as level of development, economy, political structure and stability, public education and attitude (this is "soft" criteria because they are rapidly change or vary from one region to another).

These criteria are developed \& applied by Stefan Bachu [5]. It can also be applied for small regions like oil \& gas reservoirs. Site selection for $\mathrm{CO}_{2}$ sequestration among four potential gas fields of Bangladesh [7] is analyzed here carefully according to Bachu's method where 15 important criteria are considered. The criteria are, tectonic setting, size, depth, geology, hydrogeology, geothermal, hydrocarbon potential, maturity, coal \& CBM, salts, on/offshore, climate, accessibility, infrastructure, $\mathrm{CO}_{2}$ sources. S. Bachu [6] assigned weight for all characteristics according to their importance. Thus geology, hydrogeology, geothermal, maturity, on/offshore, climate and $\mathrm{CO}_{2}$ sources are considered as most important criteria. It can also be easily proved that initial capacity of a gas field, its maturity and nearby $\mathrm{CO}_{2}$ sources would be the most valuable criteria in case of $\mathrm{CO}_{2}$ sequestration in a gas field. 
The suitability analysis of the gas fields is far more reliable after simulation takes place. The ECLIPSE simulator has been the benchmark for commercial reservoir simulation for more than 25 years, covering the entire spectrum of reservoir models, including black oil, gas field operations, compositional, thermal finite-volume, and streamline simulation. In this research, Schlumberger Eclipse (version 2010.1)-E300 portion has been used to carry whole simulation process. The grid portion is prepared by Petrel software. Simulation result analyses are the most important part that should be done carefully to interpret reservoir conditions after simulation.

\section{Materials and Methods}

Stefan Bachu's criteria for suitability analysis of $\mathrm{CO}_{2}$ sequestration can be divided into two parts, i) variable criteria which are different for the gas fields with respect to their respective existing conditions and ii) constant criteria that are dictated by geological conditions of Bangladesh.

\subsection{Analyzation of Bachu's variable criteria for potential gas fields of Bangladesh}

Criteria under this category are, size, depth, geology, hydrogeology, hydrocarbon potential, maturity, infrastructure and $\mathrm{CO}_{2}$ sources.

i) Size: Titas gas field is one of the major contributors in the supply of gas in Bangladesh. It has a size of $16 \mathrm{~km}$ by $8 \mathrm{~km}$. It can be considered as large size reservoir along with Rashidpur gas field, which has an area of $35 \mathrm{~km}$ by $7 \mathrm{~km}$. Habiganj gas field has a small area of $11.5 \mathrm{~km}$ by $4.5 \mathrm{~km}$ whereas Kailashtila gas field has a medium area of $17 \mathrm{~km}$ by $5 \mathrm{~km}$ [8]. The classes are mainly assigned with respect to each other of the gas fields.

ii) Depth, Geological and Hydrogeological condition: Titas gas reservoir includes multiple sandstone layers in the Bhuban and Bokabil formations of Miocene-Pliocene age. The depths of the gas reservoirs [8] range from about $2616 \mathrm{~m}$ to $3124 \mathrm{~m}$ below the surface. Recently BAPEX (Bangladesh Petroleum Exploration and Production Company Limited) has discovered country's deepest gas reserve at Titas around $7000 \mathrm{~m}$ under the ground. Data analysis suggests that there is no major fault but seismic study indicates relatively small faulting having down throw to the east in the crestal region adjoining the eastern flank [9]. The fault affects older section at depth of about 2800 to $3000 \mathrm{~m}$ [10]. Also, Clayton [11] identified few small faults within depths of around 2650 to $2750 \mathrm{~m}$. Other analysis also suggests the same. Water injection with reservoir depth analysis reveals that aquifer presents in a shallow depth and compaction water flow exists in the reservoir [12]. The Habiganj gas field sandstones belonging to the Surma group (Bhuban and Bokabil formations) of Miocene-Pliocene age. There are two gas zones known as upper gas sand (UGS) and lower gas sand (LGS). The upper gas sand lies at a depth of $1320 \mathrm{~m}$ where the lower gas sand has a depth of $3000 \mathrm{~m}$. Though no significant fault is yet discovered, but some analysis results indicate that there may be some big features like faults mainly in the upper gas sand of Habiganj gas field [13]. As the formation also 
contains mostly sandstones, it may be considered as 'extensively faulted and fractured'. Habiganj gas field has already been identified as a strong bottom water drive. Without considering water influx, the conventional material balance (p/z vs. Gp method) for OGIP of upper sand can be determined as 16 Tcf that appears to be overestimation of real volume, and cannot match with the present flow and pressure data. Considering bottom water drive, the Havlena-Odeh method for materials balance analysis has been applied, as the total underground withdrawal is equal to summations of water influx and gas-water expansion. The calculation of water influx by Allard-Chen and Carter-Tracy methods for Havlena-Odeh plot indicate that the average OGIP of that sand is 4.52 Tcf which is acceptable and seems more reliable with respect to the present production data [14]. So shallow distance short flow system exists here. The Rashidpur gas field has a depth of 1380-2787 $\mathrm{m}$. The volumes of shale values were low within the hydrocarbon-bearing zones of Rashidpur gas field [15] and also the major fault is of narrower width but there are numerous other small faults running $\mathrm{N}-\mathrm{S}$ trend on the eastern flank of the structure [16]. So the field is classified as 'extensively faulted and fractured'.It contains significant water bearing zones show in the table 1 for well-4 analysis.

Table 1. Permeable zones of the Rashidpur well-4 in the Rashidpur Gas Field [15].

\begin{tabular}{lllc}
\hline Zone No. & Fluid Type & Depth Range $(\mathrm{m})$ & Thickness $(\mathrm{m})$ \\
\hline 1 & Water-bearing & $1374-1402$ & 28 \\
2 & Hydrocarbon-bearing & $1447-1523$ & 76 \\
3 & Water-bearing & $1534-1550$ & 16 \\
4 & Water-bearing & $1555-1565$ & 10 \\
5 & Water-bearing & $1575-1595$ & 20 \\
6 & Water-bearing & $1635-1670$ & 35 \\
7 & Water-bearing & $1718-1740$ & 22 \\
8 & Water-bearing & $1760-1780$ & 20 \\
9 & Water-bearing & $1795-1805$ & 10 \\
10 & Water-bearing & $1855-1885$ & 30 \\
11 & Water-bearing & $1930-1960$ & 30 \\
12 & Water-bearing & $1962-1985$ & 23 \\
13 & Water-bearing & $2060-2090$ & 30 \\
14 & Water-bearing & $2180-2190$ & 10 \\
15 & Water-bearing & $2215-2225$ & 10 \\
16 & Water-bearing & $2314-2335$ & 21 \\
17 & Hydrocarbon-bearing & $2337-2350$ & 13 \\
18 & Water-bearing & $2405-2440$ & 35 \\
19 & Hydrocarbon-bearing & $2466-2483$ & 17 \\
20 & Hydrocarbon-bearing & $2668-2732$ & 64 \\
\hline
\end{tabular}

In Kailashtila gas field, there are three main gas zone (upper, middle and lower) ranging from $2280 \mathrm{~m}$ to $3045 \mathrm{~m}$. It is visible that Kailashtila gas field's lithology comprises mostly of sandstone with less shale which belongs to the Bhuban \& Bokabil formation of Surma group. According to the analysis of the four wells (KTL-2, KTL-3, 
KTL-4, KTL-5) and considering small amount of shale presence, the gas field may be classified as 'moderately faulted and fractured' [17]. Fig. 2 shows a great difference between the Analytical method with Aquifer Influx and without Aquifer Influx which indicates an active Aquifer model for the Kailashtila upper gas sand [18].

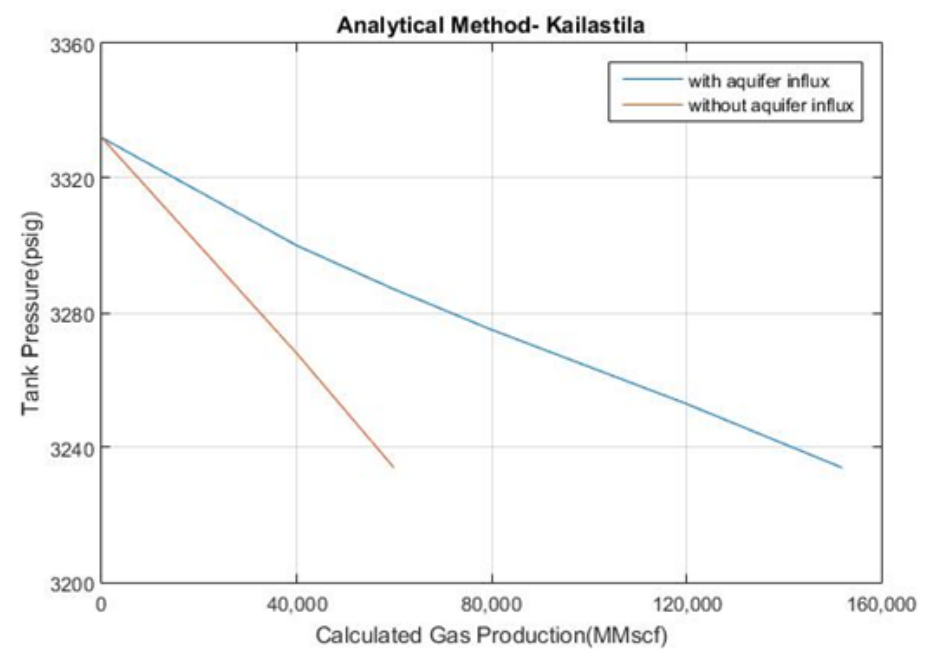

Fig. 2.Analytical Method Comparison with and without Aquifer Model for UGS [18].

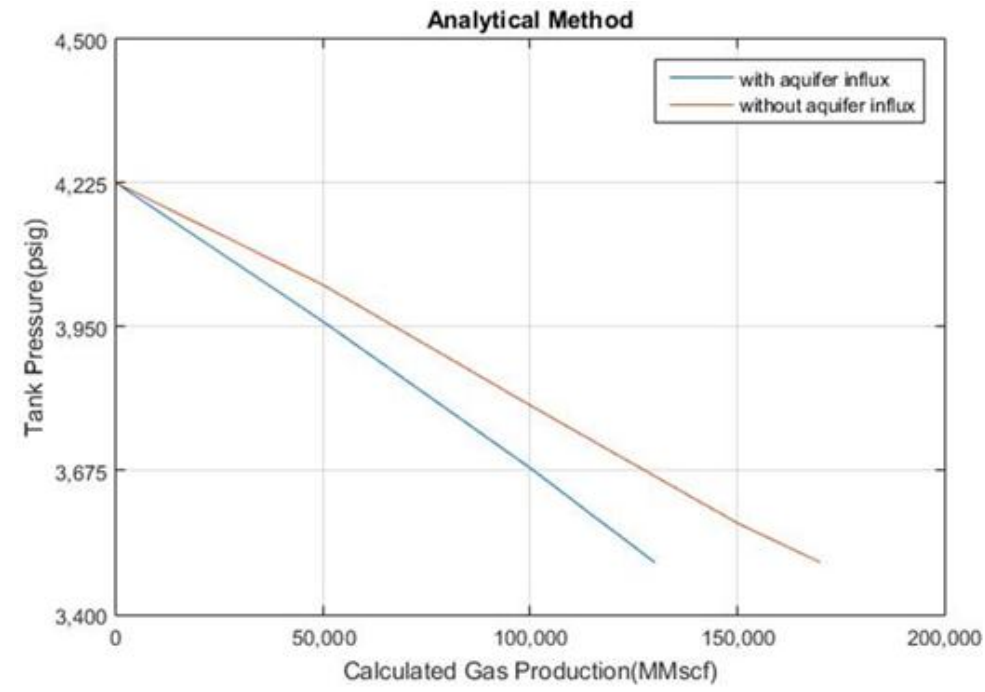

Fig. 3. Analytical Method Comparison with and without Aquifer Model for MGS [18].

Fig. 3 shows difference between the Analytical method with Aquifer Influx and without Aquifer Influx which indicates an active aquifer model for the Kailashtila middle 
gas sand. Fig. 4 shows difference between the Analytical method with Aquifer Influx and without Aquifer Influx which indicates an active Aquifer model for the Kailashtila lower gas sand. Although significant water flux occurs for upper gas sand, water flux is relatively low for middle and lower gas sand in Kailashtila gas field. So, Kailashtila gas field's hydrogeology can be classified as 'intermediate flow systems'.

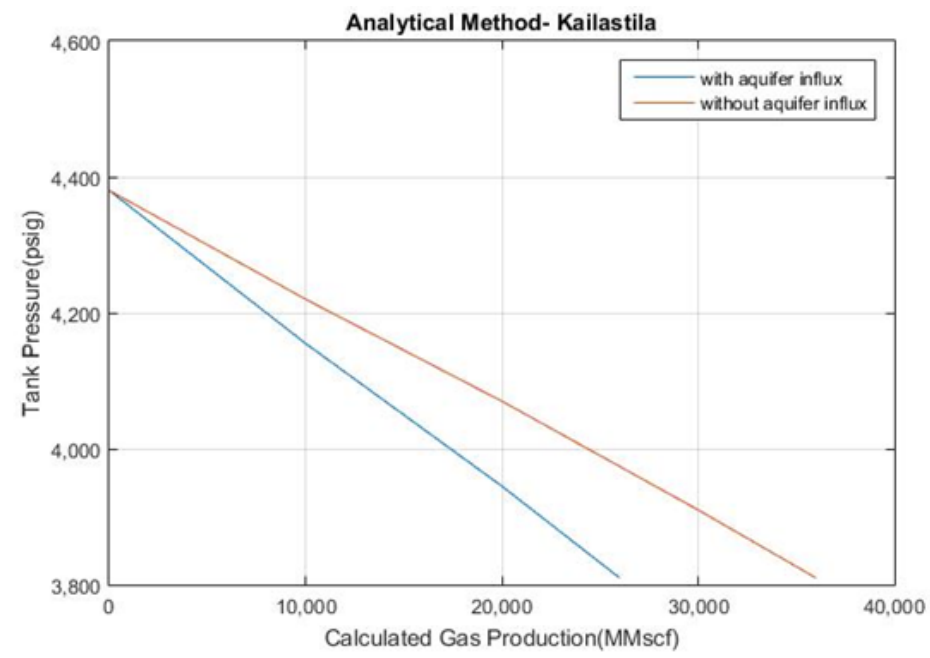

Fig. 4. Analytical method comparison with and without Aquifer model for LGS [18].

iii) Hydrocarbon potential: According to hydrocarbon reserve the gas fields can be classified as giant, large, medium or small size showing in Table 2 [8].

Table 2. Classification of hydrocarbon potential by reserve size.

\begin{tabular}{ll}
\hline Reserve size & Field category \\
\hline$>3 \mathrm{Tcf}$ & giant \\
$>1 \mathrm{Tcf}-3 \mathrm{Tcf}$ & large \\
$>300 \mathrm{Bcf}-1 \mathrm{Tcf}$ & medium \\
$<300 \mathrm{Bcf}$ & small \\
\hline
\end{tabular}

Titas gas field has been an example in which significant reserve growth has been demonstrated. Recently 1 Tcf of natural gas has been found in the gas field. Now overall Gas Initially In Place (GIIP) of the field is 8.05 Tcf gas. It is one of the giant gas reserves for Bangladesh. Petrobangla published a revised estimate of Habiganj gas field in 2011 which shows estimated GIIP of $3.68 \mathrm{Tcf}$ and an initial reserve of $2.63 \mathrm{Tcf}$ [8]. Based on the reserve size, it can be considered as 'large' hydrocarbon potential gas field. Also, Kailashtila is a large hydrocarbon potential reservoir with $2.76 \mathrm{Tcf}$ initial reserve of gas and 109 million barrels of oil [17]. The gas field is in production since 1983 and almost 2 Tcf reserve remaining according to SGFL (Sylhet Gas Fields Limited). Rashidpur gas 
field is also regarded as large hydrocarbon potential reservoir as it has a huge hydrocarbon reserve of $1.481 \mathrm{Tcf}$.

iv) Maturity: Although Titas gas field started production in 1968, the field is however yet to enter into a mature state of development and most of the 16 production/appraisal wells drilled are concentrated at the crestal part of structure [8]. Production data analysis from Table 3 also suggests that it is still producing at a significant rate and it is the second largest supplier of gas field (after Bibiyana) to the national grid. Approximately 4383 billion cubic feet gas or $57.8 \%$ of reserves has been recovered. So the gas field can classify as 'developing' in the criteria of 'maturity'.

Table 3. Daily production of Titas gas field (1st April, 2009) [19]

\begin{tabular}{|c|c|c|c|c|c|c|}
\hline \multirow[t]{2}{*}{ Wells } & \multirow[t]{2}{*}{ Formation } & \multirow[t]{2}{*}{ Production Period } & \multicolumn{3}{|c|}{ Average Daily Production } & \multirow{2}{*}{$\begin{array}{c}\text { Average Wellhead } \\
\text { Pressure (psig) }\end{array}$} \\
\hline & & & Gas (mmscfd) & Cond. (bpd) & $\begin{array}{l}\text { Water } \\
\text { (bpd) }\end{array}$ & \\
\hline Titas 1 & A Sand & April 68 - Mar 09 & 31.27 & 32.62 & 26.59 & 1885 \\
\hline Titas 2 & A Sand & May 68 - Mar 09 & 33.06 & 34.49 & 28.12 & 1900 \\
\hline Titas 3 & A Sand & July $85-$ Jan 08 & 0.0 & 0.0 & 0.0 & 0 \\
\hline Titas 4 & A Sand & Oct. 69 - Jan 08 & 32.33 & 33.73 & 27.50 & 1860 \\
\hline Titas 5 & A Sand & Jan $81-$ Mar 09 & 33.38 & 34.82 & 28.39 & 1850 \\
\hline Titas 6 & A Sand & Feb $84-$ Mar 09 & 35.00 & 36.48 & 29.77 & 1830 \\
\hline Titas 7 & A Sand & Jul 85 - Mar 09 & 32.99 & 34.43 & 28.07 & 1910 \\
\hline Titas 8 & $\mathrm{~B}$ and $\mathrm{C}$ Sand & April 68 - Mar 09 & 22.13 & 23.09 & 18.81 & 1550 \\
\hline Titas 9 & $\mathrm{~B}$ and C Sand & March 89 - Mar 09 & 31.37 & 33.16 & 26.68 & 1600 \\
\hline Titas 10 & B and C Sand & Sept 90 - Mar 09 & 14.84 & 15.49 & 12.58 & 1460 \\
\hline Titas 11 & A Sand & Jun 91 - Mar 09 & 25.93 & 27.06 & 22.06 & 2015 \\
\hline Titas 12 & A Sand & Jul 02 - Mar 09 & 21.37 & 31.79 & 1286.44 & 1725 \\
\hline Titas 13 & A Sand & Jun 00 - Mar 09 & 21.36 & 32.22 & 215.70 & 2100 \\
\hline Titas 14 & A Sand & Jun $00-$ Nov 06 & 0.0 & 0.0 & 0.0 & 0 \\
\hline Titas 15 & A Sand & May 06 - Mar 09 & 29.99 & 31.30 & 25.51 & 1966 \\
\hline Titas 16 & A Sand & Dec 05 - Mar 09 & 29.96 & 31.26 & 25.48 & 1968 \\
\hline Total & & & 394.98 & 431.94 & 1801.7 & \\
\hline
\end{tabular}

Daily production rate analysis of Habiganj gas field for the year of 2007 (Table 4) and 2017 (Table 5) shows a significant decrease in producing gas. Production of water also increases at a high rate in this time period. Also near $85 \%$ of the reserves of this field has been recovered already. So the field is in its way to mature stage. 
Table 4. Production data of well-07 and well-10 of Habiganj gas field for the year of 2007 [20].

\begin{tabular}{|c|c|c|c|c|c|c|}
\hline \multirow{2}{*}{$\begin{array}{l}\text { Date } \\
(\mathrm{M} / \mathrm{D} / \mathrm{Y})\end{array}$} & \multicolumn{3}{|l|}{ Well-07 } & \multicolumn{3}{|l|}{ Well-10 } \\
\hline & $\begin{array}{l}\text { Gas } \\
\text { (MMScf) }\end{array}$ & $\begin{array}{l}\text { FWHP } \\
\text { (Psig) }\end{array}$ & $\begin{array}{l}\text { Water } \\
\text { (bbl) }\end{array}$ & $\begin{array}{l}\text { Gas } \\
\text { (MMScf) }\end{array}$ & $\begin{array}{l}\text { FWHP } \\
\text { (Psig) }\end{array}$ & $\begin{array}{l}\text { Water } \\
\text { (bbl) }\end{array}$ \\
\hline $1 / 1 / 2007$ & 23.268 & 1600 & 4.101 & 23.004 & 1575 & 4.038 \\
\hline $1 / 2 / 2007$ & 25.693 & 1555 & 4.296 & 25.402 & 1540 & 4.265 \\
\hline $1 / 3 / 2007$ & 31.196 & 1545 & 4.516 & 30.842 & 1495 & 4.472 \\
\hline $1 / 4 / 2007$ & 35.323 & 1542 & 4.164 & 34.922 & 1491 & 4.12 \\
\hline $1 / 5 / 2007$ & 41.327 & 1525 & 4.755 & 40.858 & 1488 & 4.693 \\
\hline $1 / 6 / 2007$ & 42.097 & 1486 & 4.875 & 41.619 & 1484 & 4.80 \\
\hline $1 / 7 / 2007$ & 42.953 & 1468 & 4.894 & 42.466 & 1468 & 4.837 \\
\hline $1 / 8 / 2007$ & 43.245 & 1437 & 5.573 & 42.754 & 1445 & 5.523 \\
\hline $1 / 9 / 2007$ & 43.837 & 1412 & 5.548 & 43.349 & 1435 & 5.46 \\
\hline $1 / 10 / 2007$ & 43.633 & 1414 & 5.12 & 43.147 & 1432 & 5.095 \\
\hline
\end{tabular}

Table 5. Daily production data of BGFCL [21]

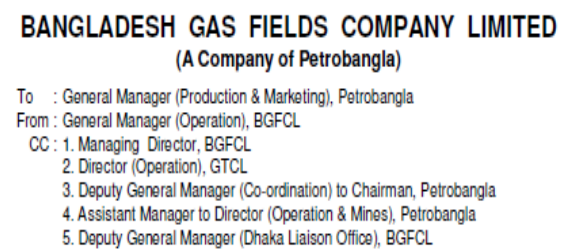

3. Deputy General Manager (Co-ordination) to Chairman, Petrobangla

4. Assistant Manager to Director (Operation \& Mines), Petrobangla

5. Deputy General Manager (Dhaka Liaison Office), BGFCL

Sub : Daily Production \& Sales Report Date : 11 October 2017

\begin{tabular}{|c|c|c|c|c|c|c|c|c|c|c|c|c|c|c|c|c|}
\hline \multirow{2}{*}{$\begin{array}{l}\text { Well } \\
\text { No. }\end{array}$} & \multicolumn{3}{|c|}{ TITAS FIELD } & \multicolumn{3}{|c|}{ HABIGANJ FIELD } & \multicolumn{3}{|c|}{ BAKHPABAD FIELD } & \multicolumn{3}{|c|}{ NARSINGDI FIELD } & \multicolumn{4}{|c|}{ MEGHNA FIELD } \\
\hline & Avg Prod. & Avg.WHP & Tolal Cond. & $\begin{array}{l}\text { Avg.Prod. } \\
\text { gusccopl }\end{array}$ & AvgWHP & $\begin{array}{l}\text { Total Cond. } \\
\text { Prod }\end{array}$ & \begin{tabular}{|l|} 
Avg Prod. \\
Muscros)
\end{tabular} & AvgWHP & Total Cond. & Avg Prod. & AvgWHP & Total Cond. & Avg Prod. (I) & MSCFD) & Avg WHP & Total Cond. \\
\hline 1 & 24.492 & 915 & \multirow{7}{*}{395.0} & 0.000 & 0 & \multirow{7}{*}{11.7} & 0.000 & 0 & \multirow{7}{*}{150} & 16.897 & 1165 & \multirow{7}{*}{45.586} & Short String & 12.676 & 1440 & \multirow{7}{*}{21.5} \\
\hline 2 & 32.855 & 1100 & & 0.000 & 0 & & 1.378 & 262 & & 10.620 & 1050 & & & & & \\
\hline 3 & 0.000 & 0 & & 36.075 & 1482 & & 6.367 & 373 & & & & & & & & \\
\hline 4 & 32855 & 1040 & & 36.075 & 1453 & & 0.000 & 0 & & & & & & & & \\
\hline 5 & 33.500 & 1030 & & 26.051 & 1443 & & 5.052 & 1630 & & & & & & & & \\
\hline 6 & 33.550 & 1210 & & 15.054 & $13 \pi$ & & 0.000 & 0 & & & & & & & & \\
\hline 7 & 30.850 & 1150 & & 40.687 & 1330 & & 0.000 & 0 & & & & & & & & \\
\hline 8 & 18.255 & 1020 & \multirow{2}{*}{$\begin{array}{l}\text { Total Walar } \\
\text { Prod.(BBL) }\end{array}$} & 0.000 & - & \multirow{2}{*}{$\begin{array}{l}\text { Tola Water } \\
\text { Prod.(BBL) }\end{array}$} & 8.473 & 504 & \multirow{2}{*}{$\begin{array}{l}\text { Tolal Waler } \\
\text { Prod(BBL) }\end{array}$} & & & \multirow{2}{*}{$\begin{array}{l}\text { Total Walar } \\
\text { Prod.(BBL) }\end{array}$} & & & & \multirow{2}{*}{$\begin{array}{l}\text { Tolal Walar } \\
\text { Prod,(BBL) }\end{array}$} \\
\hline 9 & 22656 & 1050 & & 0.000 & - & & 9.462 & 1013 & & & & & & & & \\
\hline 10 & 21.500 & 1160 & \multirow{19}{*}{1334.0} & 39.166 & 1320 & \multirow{19}{*}{56.1} & 3.833 & 1031 & \multirow{19}{*}{91.0} & & & \multirow{19}{*}{29.288} & & & & \multirow{19}{*}{5.9} \\
\hline 11 & 29.450 & 1285 & & 27. 475 & 1417 & & & & & & & & & & & \\
\hline 12 & 14.050 & 1496 & & & & & & & & & & & & & & \\
\hline 13 & 20.200 & 1095 & & & & & & & & & & & & & & \\
\hline 14 & 23.150 & 1210 & & & & & & & & & & & & & & \\
\hline 15 & 0.000 & 0 & & & & & & & & & & & & & & \\
\hline 16 & 26.655 & 1220 & & & & & & & & & & & & & & \\
\hline 17 & 18.729 & 1155 & & & & & & & & & & & & & & \\
\hline 18 & 19.500 & 1170 & & & & & & & & & & & & & & \\
\hline 19 & 16.750 & 1415 & & & & & & & & & & & & & & \\
\hline 20 & 9.751 & 1420 & & & & & & & & & & & & & & \\
\hline 21 & 7.655 & 1280 & & & & & & & & & & & & & & \\
\hline 22 & 12.150 & 1000 & & & & & & & & & & & & & & \\
\hline 23 & 16.493 & 2320 & & & & & & & & & & & & & & \\
\hline 24 & 7.555 & 1235 & & & & & & & & & & & & & & \\
\hline 25 & 16.971 & 1315 & & & & & & & & & & & & & & \\
\hline 26 & 26.753 & 1865 & & & & & & & & & & & & & & \\
\hline 27 & 16.653 & 1260 & & & & & & & & & & & & & & \\
\hline TOTAL & 532.978 & & & 220.590 & & & 34.565 & & & 27.517 & & & & 12.676 & & \\
\hline
\end{tabular}


For Rashidpur gas field, an analysis shows that if wells produce at a constant flow rate, then Rashidpur-1, 3, 4, 7 wells will run for next 58.90, 16.90, 32.72 and 32.67 year respectively [22]. Thus it may consider as developing reservoir.

v) Infrastructure and $\mathrm{CO}_{2}$ sources: The overall infrastructure is in moderate condition for Titas gas field. Significant number of wells are producing in this giant gas field. The gas field also surrounded by major carbon dioxide sources as it is near Dhaka. Big Ashuganj power plant is situated at a near distance approximately $22 \mathrm{~km}$ and other small sources also available. Moderate infrastructure with good well condition is assumed for Hobiganj gas field. It places at a near distance of Titas gas field and surrounds with major $\mathrm{CO}_{2}$ sources like Shahjibazar power plant \& rental, Habiganj power plant and other small sources. However, Kailashtila gas field has only one big (fenchuganj) power plant around and also has little build-in infrastructure. For Rashidpur gas field, minor infrastructure presents due to only 8 wells for this large gas field and also as a result of developing reservoir, all facilities will not be yet included. Moderate classification for $\mathrm{CO}_{2}$ sources (i.e. Shahjibazar power \& rental, Habiganj power plant, Ashuganj power plant) as they situated at a distance not too close.

\subsection{Analyzation of Bachu's constant criteria for potential gas fields of Bangladesh}

Geological condition of Bangladesh dictates constant criteria; tectonic setting, geothermal condition, coal \& CBM, salts, on/off shore, climate, accessibility.

The tectonic framework of Bangladesh may be broadly divided into two main units: 1) stable platform in the northwest and 2) deep (geosynclinal) basin to the east and southeast. A narrow northeast-southeast trending 'Hinge zone' separate the above two units diagonally. The geosynclinal basin is subdivided into two parts: 1) fold belt in the east, and 2) foredeep in the west (Fig. 5).

The Bengal Basin is located at a junction point of the three lithospheric plates viz. the Indian Plate, the Eurasian Plate and the Burma Plate posing high seismic susceptibility in the region according to West Bengal Disaster Management Department. The earthquakes in the Tripura fold belt are much more frequent than in the Eocene Hinge zone because of the plate boundary activity. In addition, adjacent Indo-Burma subduction zone helps identifying the fold belt region as 'Convergent Oceanic'. The fold structures favoring gas accumulation occur in the eastern fold belt part and thus most of the gas fields are located in the eastern part of the country which are mainly onshore gas reservoirs. No salt beds or dome is present in the gas reservoirs of Bangladesh. Also, a huge amount of $\mathrm{CO}_{2}$ sources present in this region. Total $\mathrm{CO}_{2}$ emissions from large point sources in Bangladesh in the IEAGHG R\&D program database amount to some $17 \mathrm{Mt} \mathrm{CO}_{2}$. The coal fields occupy in the northwest stable platform. Average temperature of this region is said to be $25{ }^{\circ} \mathrm{C}$. The geothermal gradient [5] of the fold belt region of Bangladesh ranges from $20{ }^{\circ} \mathrm{C} / \mathrm{km}$ to 30 ${ }^{\circ} \mathrm{C} / \mathrm{km}$. This results to an overall P-T diagram like Fig. 6. It relates to warm basin behavior according to phase behavior of $\mathrm{CO}_{2}$ [6]. 


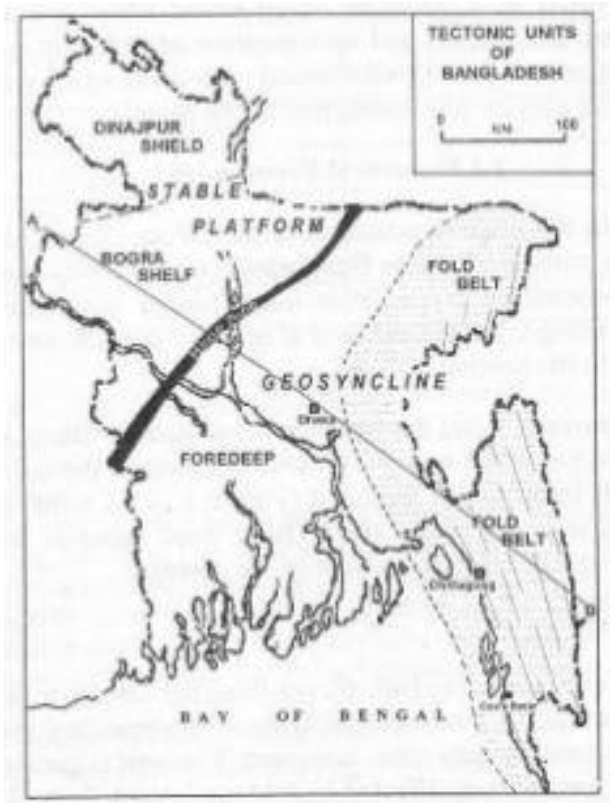

Fig. 5. Tectonics units of Bangladesh [8].

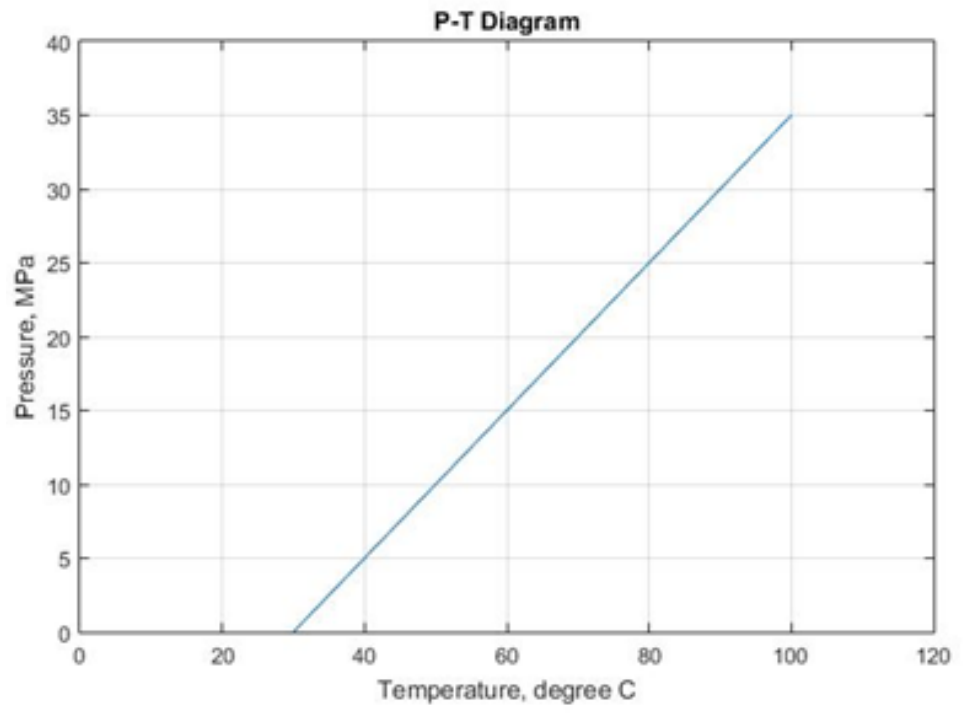

Fig. 6. Overall P-T diagram for fold belt region of Bangladesh.

\subsection{Simulation process}

A simulation model is one which shows the main features of a real system, or resembles it in its behavior, but is simple enough to make calculations on [23]. To establish a tangential real system, huge amount of data is required to provide in data file. Our data 
file is generated by using RUNSPEC, GRID, PROPS, SOLUTION, SUMMARY and SCHEDULE section in GASWAT (i.e., modeling gas phase/aqueous phase) option within "Eclipse 300" portion [24].

The simulation is done for Titas gas field. Analysis of Haq [25] indicates a complete ending of Titas gas field's life approximately in the year of 2060. The planning for carbon sequestration in this study is as such planned to start from 2060. Six injection wells (well no. $2,5,6,7,11 \& 13$ ) are used in this model to inject carbon dioxide gas in 'A' sand for 50 years. Injection rates of the wells are determined according to their respective production rates. Injection locations are distributed into five layers (A1, A2, A3, A4U, $\mathrm{A} 4 \mathrm{~L}$ ) of ' $A$ ' sand such that no well will face shut-in situation in future. Table 6 contains information about injections wells.

Table 6. Injection well conditions.

\begin{tabular}{llll}
\hline \multirow{2}{*}{ Well no. } & $\begin{array}{l}\text { Injection rate } \\
\text { (MMSCFD) }\end{array}$ & from & Injection layer \\
\cline { 3 - 4 } & 25 & A3 & A4L \\
\hline 2 & 30 & A1 & A3 \\
6 & 30 & A1 & A3 \\
7 & 30 & A4U & A4L \\
11 & 25 & A4U & A4L \\
13 & 20 & A1 & A3 \\
\hline
\end{tabular}

Fracture pressure is determined to set injection well shut-in pressure value. According to Haq [25], initial pressure at an average depth of $8800 \mathrm{ft}$ of Titas gas field is 4005.9 psia. This value is added by minimum matrix stress to find overall fracture pressure of ' $\mathrm{A}$ ' sand. Matrix stress ratio (0.775) and vertical overburden stress $(0.96$ for $100 \mu \mathrm{s} / \mathrm{ft}$ at 8900 ft [26]) are calculated from Pennebaker correlation [27]. Then the value of minimum matrix stress will be 3442 psia and fracture pressure will be 7448 psia. For safety, injection well shut-in pressure is set to the limit of 6000 psia.

The entire cartesian grid of 'A' sand is prepared using Petrel software. The simulation model is a non-orthogonal corner-point model. ' $\mathrm{A}$ ' sand contains 50 grid blocks in $\mathrm{X}$ direction with average dimension $252 \mathrm{~m}$ and 100 grid blocks in $\mathrm{Y}$ direction with average dimension $264 \mathrm{~m}$ in each of the five layers. Average thickness of layers A1, A2, A3, A4U and $\mathrm{A} 4 \mathrm{~L}$ are $24,178,112,79$, and $50 \mathrm{ft}$, respectively. The permeability distribution ranges from 12 to $30 \mathrm{mD}$ in section A that is determined by a hydraulic flow element study [28].

Four components, $\mathrm{C} 1\left(\mathrm{CH}_{4}\right), \mathrm{C} 2\left(\mathrm{C}_{2} \mathrm{H}_{6}\right), \mathrm{CO}_{2}, \mathrm{H}_{2} \mathrm{O}$ have to be considered with their critical properties, acentric factor, Molecular Weight (MW) for PROPS section. All the properties are recorded in field units with essential command within simulator. Table 7 contains the information. 
Table 7. Properties of the components [29].

\begin{tabular}{llllll}
\hline Component & $\begin{array}{l}\text { Critical } \\
\text { temperature } \\
\text { (TCRIT) }\end{array}$ & $\begin{array}{l}\text { Critical } \\
\text { pressure } \\
\text { (PCRIT) }\end{array}$ & $\begin{array}{l}\text { Critical } \\
\text { compressibility factor } \\
\text { (ZCRIT) }\end{array}$ & $\begin{array}{l}\text { Acentric } \\
\text { factor } \\
\text { (ACF) }\end{array}$ & $\begin{array}{l}\text { Molecular } \\
\text { weight } \\
\text { (MW) }\end{array}$ \\
\hline $\mathrm{C} 1\left(\mathrm{CH}_{4}\right)$ & 343.1 & 667.8 & 0.289 & 0.0115 & 16 \\
$\mathrm{C} 2\left(\mathrm{C}_{2} \mathrm{H}_{6}\right)$ & 549.8 & 707.8 & 0.285 & 0.0908 & 30 \\
$\mathrm{CO}_{2}$ & 547.6 & 1070.9 & 0.274 & 0.2250 & 44 \\
$\mathrm{H}_{2} \mathrm{O}$ & 1165.1 & 3203.6 & 0.230 & 0.3210 & 18 \\
\hline
\end{tabular}

The ZMFVD function of PROPS section is assembled with approximate values assumed with respect to abandonment condition of the gas field. Abandoned reservoir temperature is considered similar to present condition $\left(188^{\circ} \mathrm{F}\right)$. GSF (gas saturation factor) and WSF (water saturation factor) values are prepared by SCAL.

Initial equilibration conditions, which are the characteristics of abandonment condition in this case, are specified in solution section. Summary file of the simulation process is generated in summary section.

\section{Results}

\subsection{Suitability result}

As stated in the introduction chapter: geology, hydrogeology, geothermal, maturity, on/off shore, climate, $\mathrm{CO}_{2}$ sources are the most important criteria in selecting suitable location for carbon dioxide sequestration. Only hydrogeological condition of Kailashtila gas field and maturity of Habiganj gas field are better than Titas gas field. For all other criteria, Titas gas field provides the best condition. Also from scoring and ranking of Hoque et al. [30], Titas gas field has been proved to be geologically better gas field for carbon sequestration among the gas fields of Bangladesh.

\subsection{Eclipse simulation result}

Gas saturation of the field (SGAS), field gas injection total (FGIT), field gas in place (FGIP) and field pressure( FPR) have been analyzed after 50 years of carbon dioxide simulation process. Carbon dioxide accumulates in the lower part of the reservoir as expected. It sweeps existing hydrocarbon gases upwards. As a result, saturation of gas in the bottom portion of the reservoir is relatively small than upper part of the reservoir (Fig. 7).

A total of $2.92 \mathrm{Tcf}$ carbon dioxide gas has been sequestrated after 50 years of time period (Fig. 8). This huge amount of gas has been injected without any break of continuation. 2.58 Tcf of existing (abandon) hydrocarbon gas and 2.92 Tcf of carbon dioxide gas sums up a total of $5.5 \mathrm{Tcf}$ gas in the reservoir (Fig. 9). It is lower than the capacity of Titas gas field. FGIT vs time, FGIP vs time graphs are showed here which are prepared by using office option within eclipse. 
Field pressure of the gas field has been escalated to an amount of 2410 psia after the ending of carbon dioxide injection (Fig. 10). The value is much lower than the fracture pressure (7530 psia) and as such, reservoir shouldn't face any fracture problem within this time.

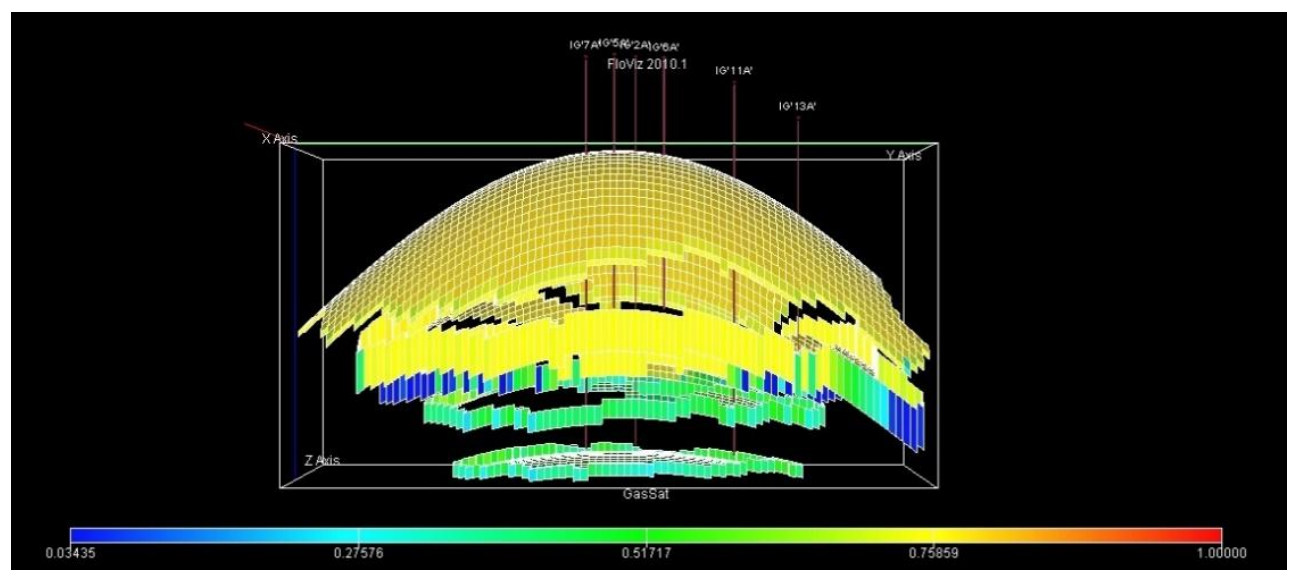

Fig. 7. Gas saturation 3D model of Titas gas field after carbon dioxide simulation (using FloViz option-front view).

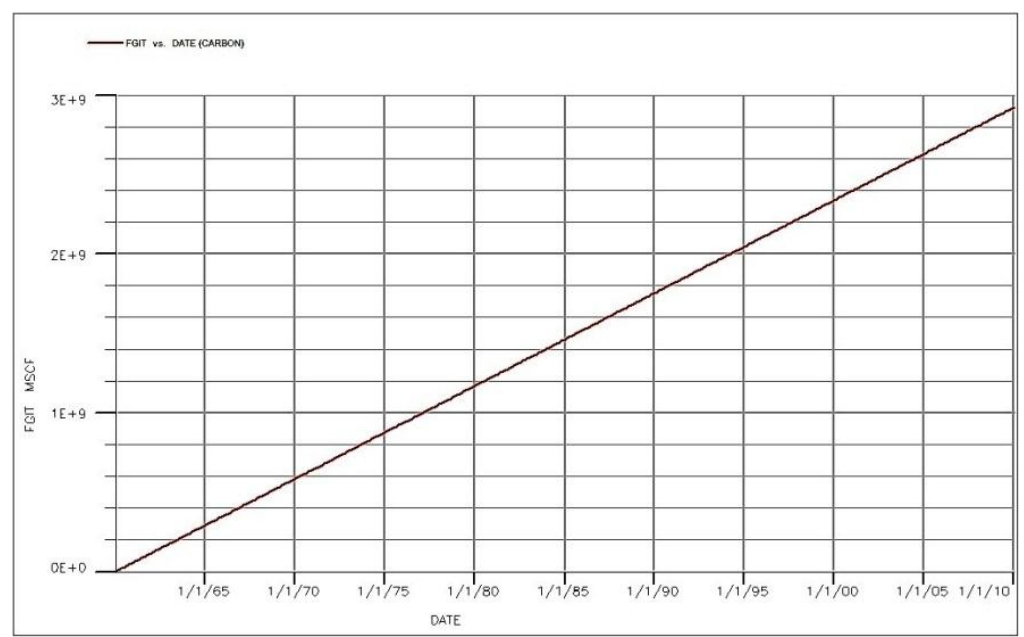

Fig. 8. Field Gas Injection Total (FGIT) vs time graph. 


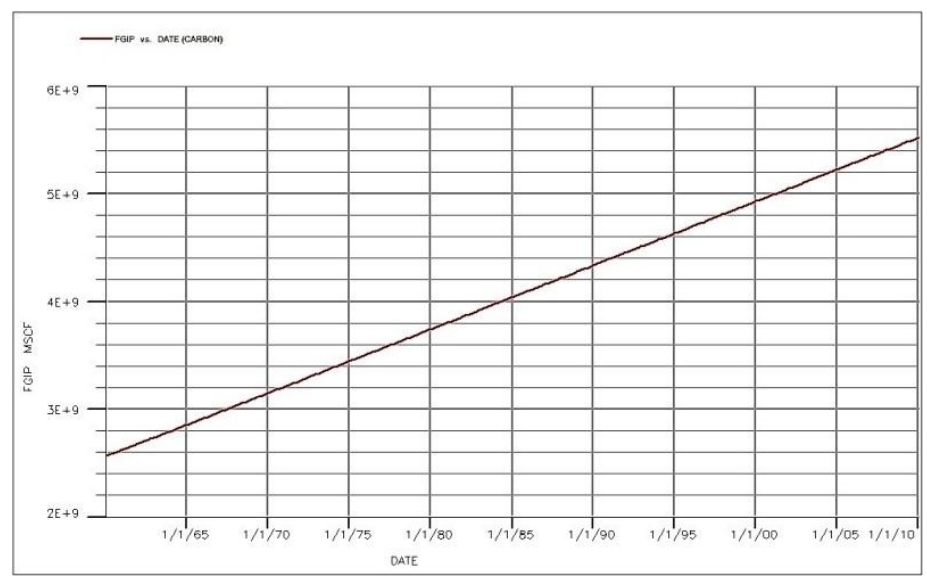

Fig. 9. Field Gas In Place (FGIP) vs time graph.

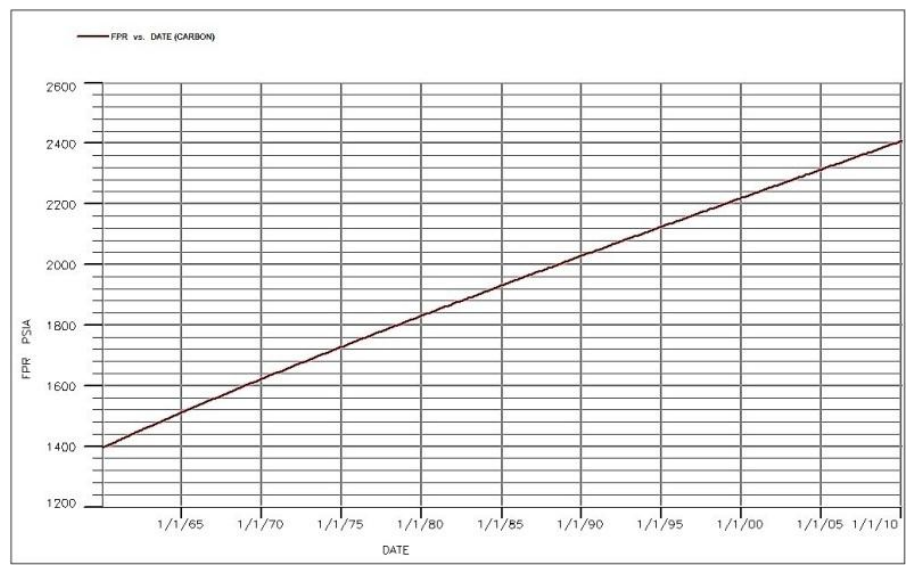

Fig. 10. Field Pressure (FPR) vs time graph.

\section{Discussion}

Titas gas field is one of the main gas fields of Bangladesh which serves to the energy sector of this country at large in present time. The geological criteria for carbon dioxide sequestration are fit to this field more perfectly than other gas fields. Huge storage capacity of this gas field should be used for environmental purpose. The field will be abandoned approximately around the year of 2060 and immediately after that period, carbon dioxide sequestration project can be undertaken using the existing wells.

As Titas gas field is one of the giant gas fields of Bangladesh which has GIIP of 8.05 Tcf, simulation result is completely in accordance with real condition. $2.92 \mathrm{Tcf}_{\mathrm{CO}_{2}}$ gas sequestration with increased field pressure of 2410 psia can be considered as safe implementation of $\mathrm{CO}_{2}$ sequestration project. The results of this study is extensively 
dependent on the data used from different sources. However, it is to be noted that the integrity of the caprocks and lateral seals of gas fields should be investigated for better understanding on the potentiality of gas fields. The feasibility of the project would be more reliable if economic analysis can be made. Different simulation approaches can also be undertaken for determining the accuracy of the result.

\section{Acknowledgment}

We express deep respect to our respectable teachers Tareq Uz Zaman and Md. Nahin Mahmood for helping us through the entire process. We are also thankful to Shafaet Jamil for helping and instructing us about the use of software and data base.

\section{Appendices}

Appendix A: Eclipse raw DATA file

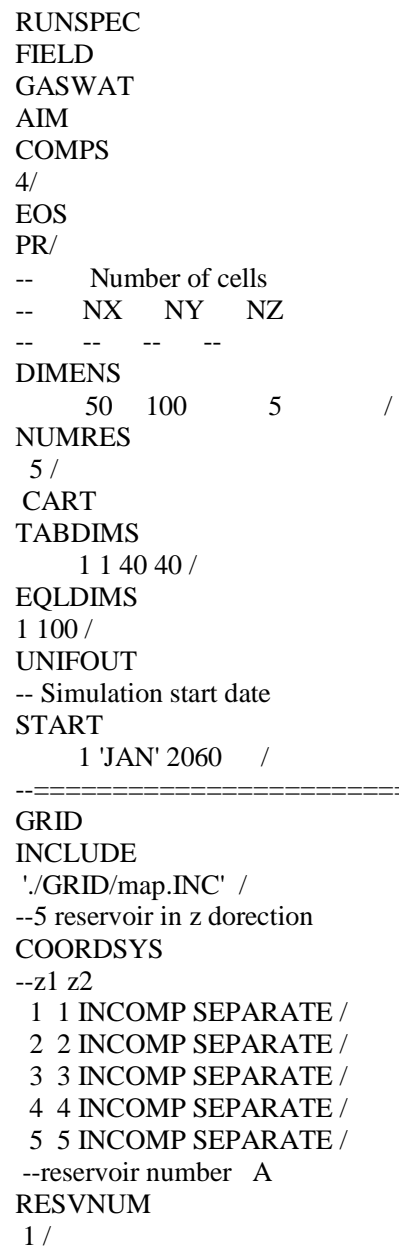


BOX

$150110011 /$

INCLUDE

'./GRID/A/A1/coord.INC' /

INCLUDE

'./GRID/A/A1/zcorn.INC' /

INCLUDE

'./GRID/A/A1/actnum.INC' /

ENDBOX

RESVNUM

21

BOX

$150110022 /$

INCLUDE

'./GRID/A/A2/coord.INC' /

INCLUDE

'./GRID/A/A2/zcorn.INC' /

INCLUDE

'./GRID/A/A2/actnum.INC' /

ENDBOX

RESVNUM

$3 /$

BOX

$150110033 /$

INCLUDE

'./GRID/A/A3/coord.INC' /

INCLUDE

'./GRID/A/A3/zcorn.INC' /

INCLUDE

'./GRID/A/A3/actnum.INC' /

ENDBOX

RESVNUM

4 /

BOX

150110044 /

INCLUDE

'./GRID/A/A4U/coord.INC' /

INCLUDE

'./GRID/A/A4U/zcorn.INC' /

INCLUDE

'./GRID/A/A4U/actnum.INC' /

ENDBOX

RESVNUM

$5 /$

BOX

$150110055 /$

INCLUDE

'./GRID/A/A4L/coord.INC' /

INCLUDE

'./GRID/A/A4L/zcorn.INC' /

INCLUDE

'./GRID/A/A4L/actnum.INC' / ENDBOX

BOX

$150110015 /$ 


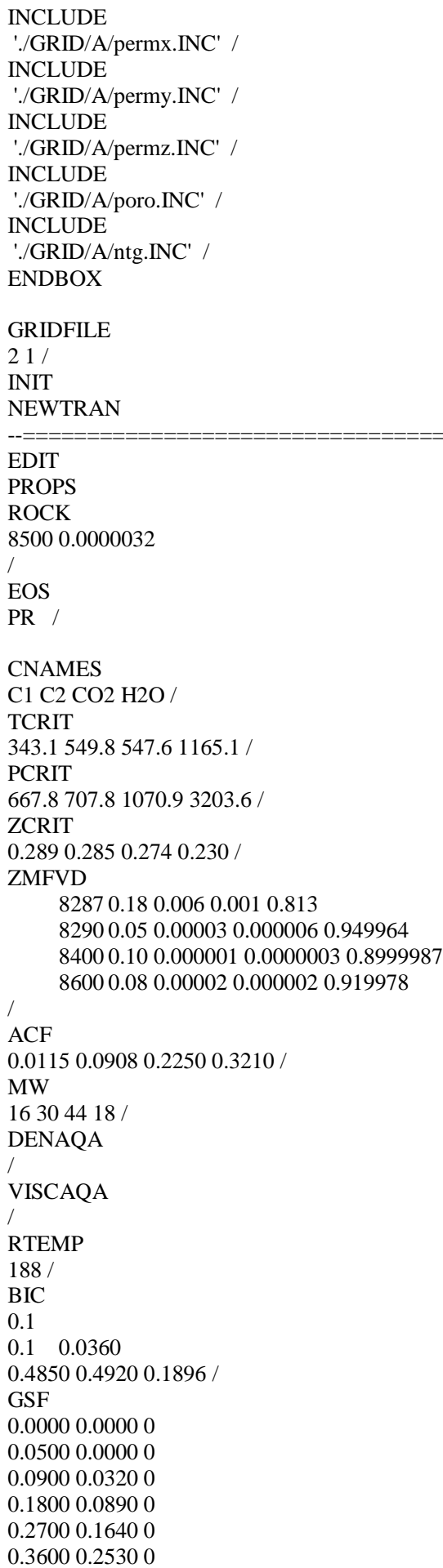




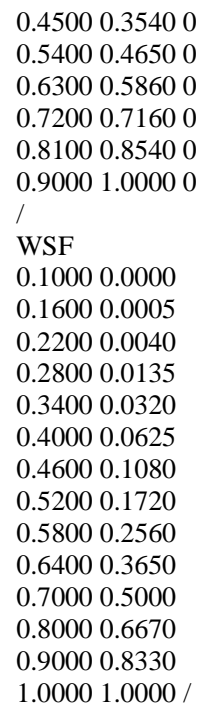

\section{REGIONS}

SOLUTION

-- Initial equilibration conditions

$\begin{array}{lllll}-- & \text { Datum Pi@datum GWC } & \text { Pc@WOC } & 10 & 11\end{array}$

EQUIL

$\begin{array}{lllllll}8287 & 1440 & 8900 & 0 & 0 & 1^{*}\end{array}$

/

RPTRST

PRESSURE SWAT SGAS DENG DENW AMF XMF YMF/

\section{SUMMARY}

ALL

RUNSUM

-- Create Excel readable Run Summary file (.RSM)

EXCEL

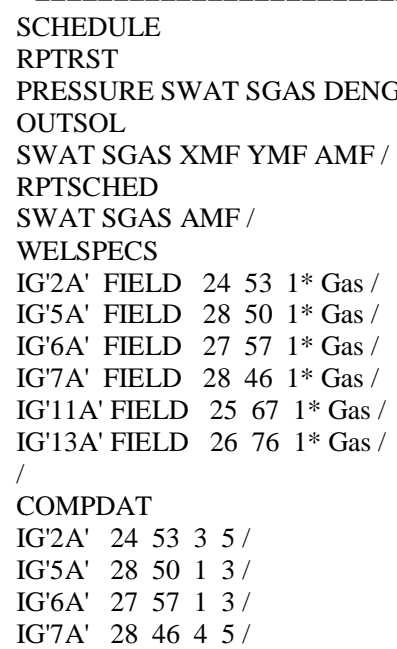


IG'11A' $256745 /$

IG'13A' $2676 \quad 13 /$

I

WELLSTRE

-- C1 C2 CO2 H2O

InjG 0.00 .01 .00 .0 /

I

--Set gas injection rates

WINJGAS

IG'2A' STREAM InjG /

IG'5A' STREAM InjG /

IG'6A' STREAM InjG /

IG'7A' STREAM InjG /

IG'11A' STREAM InjG /

IG'13A' STREAM InjG /

/

WCONINJE

IG'2A' GAS OPEN RATE $250001 * 6000$ /

IG'5A' GAS OPEN RATE $300001 * 6000 /$

IG'6A' GAS OPEN RATE $300001 * 6000$ /

IG'7A' GAS OPEN RATE $300001 * 6000$ /

IG'11A' GAS OPEN RATE 25000 1*6000/

IG'13A' GAS OPEN RATE $200001 * 6000$ /

I

DATES

1 'FEB' 2060

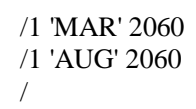

/1 'MAR' 2060

/1 'AUG' 2060

/

/1 'APR' 2060

/1 'MAY' 2060

/1 'OCT' 2060

/1 'JUN' 2060

/1 'SEP' 2060

/1 'DEC' 2060

/

\section{DATES}

1 'JAN' 2061

/1 'FEB' 2061

/1 'JUL' 2061

/1 'DEC' 2061

11 'NOV' 2061

/

\section{DATES}

1 'JAN' 2062

/1 'JUN' 2062

$/ 1$ 'NOV' 2062

/

\section{DATES}

1 'JAN' 2063

/1 'JUL' 2065

/1 'JAN' 2068

/1 'JUL' 2070

/1 'JAN' 2073

/1 'JUL' 2075

/1 'JAN' 2078

/1 'JUL' 2080

/

\section{DATES}

1 'JAN' 2081

/1 'JAN' 2086

/1 'JAN' 2091

/1 'JAN' 2096

/

DATES

1 'JAN' 2101

1 'JAN' 2102

1 'JAN' 2103
/1 'FEB' 2062

11 'JUL' 2062

/1 'DEC' 2062

/1 'JUL' 2063

/1 'JAN' 2066

/1 'JUL' 2068

/1 'JAN' 2071

/1 'JUL' 2073

/1 'JAN' 2076

/1 'JUL' 2078

I

/1 'JAN' 2082

/1 'JAN' 2087

/1 'JAN' 2092

/1 'JAN' 2097

/1 'JUL' 2076
/1 'JAN' 2085

/1 'JAN' 2090

/1 'JAN' 2095

/1 'JAN' 2100

\section{/1 'MAR' 2062} /1 'AUG' 2062 /

/1 'APR' 2062

/1 'SEP' 2062

11 'MAY' 2062

/1 'OCT' 2062

/1 'JAN' 2064

/1 'JUL' 2066

/1 'JAN' 2069

/1 'JUL' 2071

/1 'JAN' 2074

/1 'JAN' 2079

/1 'JUL' 2064

/1 'JAN' 2067

/1 'JUL' 2069

/1 'JAN' 2072

/1 'JUL' 2074

/1 'JAN' 2077

/1 'JUL' 2079

/1 'JAN' 2083

/1 'JAN' 2088

/1 'JAN' 2084

/1 'JAN' 2089

/1 'JAN' 2094

/1 'JAN' 2099

/1 'MAY' 2061

/1 'OCT' 2061

/1 'JAN' 2065

/1 'JUL' 2067

/1 'JAN' 2070

/1 'JUL' 2072

/1 'JAN' 2075

/1 'JUL' 2077

/1 'JAN' 2080

/1 'JAN' 2093

/1 'JAN' 2098 


1 'JAN' 2104
1 'JAN' 2105
1 'JAN' 2106
1 'JAN' 2107
1 'JAN' 2108
1 'JAN' 2109
1 'JAN' 2110

Grid files are generated by Schlumberger Petrel 2013 software. All data files are uploaded in '4TU.Centre'. dataset: https://doi.org/10.4121/uuid:e8ae2444-84f0-4410-bc82-210376ef5e64

\section{Appendix B: Fracture pressure determination of Titas gas field}

For minimum matrix stress $\left(\sigma_{\min }\right)$ and formation pore pressure $\left(\mathrm{P}_{\mathrm{f}}\right)$, fracture pressure $\left(\mathrm{P}_{\mathrm{ff}}\right)=\sigma_{\min }+\mathrm{P}_{\mathrm{f}}[26]$

Again, $\sigma_{\min }=\mathrm{F}_{\sigma}\left(\sigma_{\mathrm{ob}}-\mathrm{P}_{\mathrm{f}}\right)$; where, $\mathrm{F}_{\sigma}=$ Matrix stress ratio and $\sigma_{\mathrm{ob}}=$ Vertical overburden stress = Avg. overburden gradient * Depth

Now, at a depth of $8800 \mathrm{ft}$ in Titas gas field, formation pore pressure $\left(\mathrm{P}_{\mathrm{f}}\right)=4005.9$ psia [25]

$$
\text { Matrix stress ratio }\left(\mathrm{F}_{\sigma}\right)=0.775 \text { (from fig. 11) }
$$

From sonic log data of Titas gas field[26], 100 $\mu \mathrm{s} / \mathrm{ft}$ interval transit time is found approximately at a depth of $8900 \mathrm{ft}$. Then, from fig. 12, Avg. vertical overburden gradient $=0.96 \mathrm{psi} / \mathrm{ft}$.

So, Vertical overburden stress $\left(\sigma_{\mathrm{ob}}\right)=0.96 * 8800=8448 \mathrm{psi}$

Then, Minimum matrix stress $\left(\sigma_{\min }\right)=0.775(8448-4005.9)=3442 \mathrm{psi}$

Now, Fracture pressure $\left(\mathrm{P}_{\mathrm{ff}}\right)=3442+4005.9=7448 \mathrm{psi}$

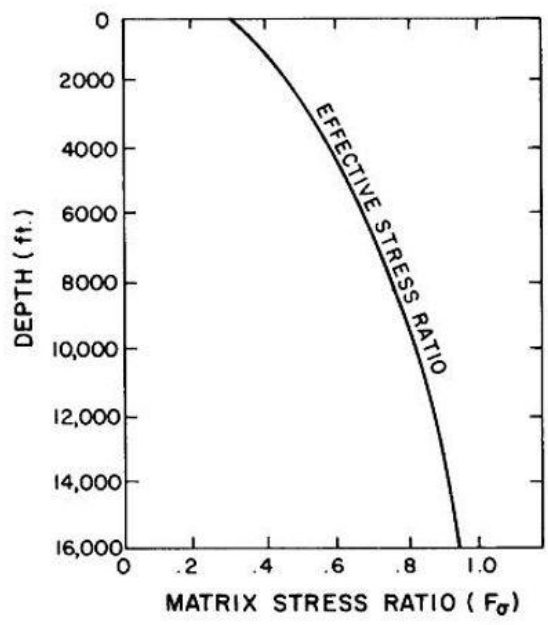

Fig. 11. Pennebaker Correlation for Effective Stress Ratio [27]. 


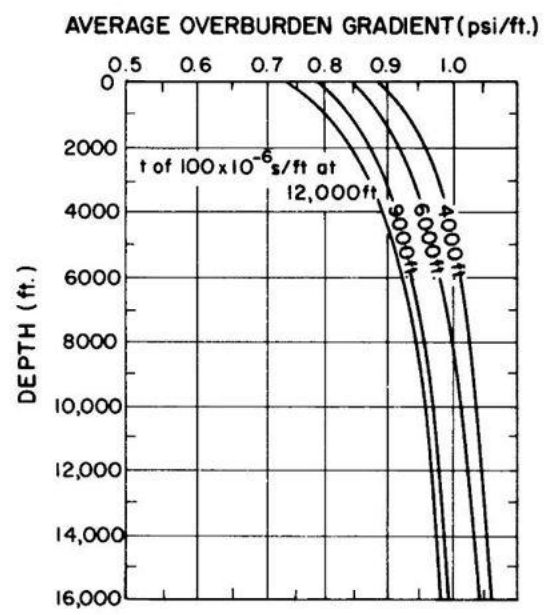

Fig.12. Pennebaker correlation for vertical overburden stress [27].

\section{References}

1. J. Alam, J. Econ. Financ. (ISOR JEF), 5, 36 (2014). https://doi.org/10.9790/5933-05613641

2. M. M. Rahman and M. A. Kashem, Energy Policy 110, 600 (2017). https://doi.org/10.1016/j.enpol.2017.09.006

3. B. G. Gunter and A. A. Rahman, Environ. Econ. 3, 58 (2012).

4. M. S. K. Sarkar, S. Sadeka, M. M. H. Sikdar and Badiuzzaman, Asia Pac. J. Energy Environ. 2(3), 175 (2015).

5. S. Bachu, Energy Convers. Manage. 43, 87 (2002). https://doi.org/10.1016/s0196-8904(01)00009-7

6. S. Bachu, Environ. Geol. 44, 277 (2003). https://doi.org/10.1007/s00254-003-0762-9

7. IEAGHG, In: A Regional Assessment of the Potential for $\mathrm{CO}_{2}$ Storage in the Indian Subcontinent (IEAGHG R\&D Programme Report, Cheltenham, 2008), pp.89-96.

8. B. Imam, Energy Resources of Bangladesh (University Grants Commission of Bangladesh, Dhaka, 2005).

9. M. S. Islam, M. A. Islam, M. H. Latif, M. Aftabuzzaman, S. M. Rahman, M. I. Molla, and M. R. Shalaby, J. Geol. Soc. INDIA, 89, 471 (2017). https://doi.org/10.1007/s12594-017-0630-y

10. Bangladesh Oil, Gas and Mineral Corporation (BOGMC), In: Well Completion Report, Titas \# 11, Geol. Evalu. Div. (Petrobangla, Dhaka, 1990).

11. N. J. Clayton, The Final Report of Seislog Processing and Interpretation (Titas Gas Field, Teknica Petrobangla, 1988).

12. M. S. Shah and H. M. Z. Hossain, Bangladesh J. Sci. Ind. Res. 50, 29 (2015). https://doi.org/10.3329/bjsir.v50i1.23807

13. M. S. Islam and L.N. Jahan, Int. J. Oil Gas Coal Eng. 1, 7 (2013). https://doi.org/10.11648/j.ogce.20130101.12

14. M. M. Nawab and M. S. Hossain, Bangl. Geosci. J. 16, 69 (2010).

15. A. R. M. T. Islam, M. A. Habib, M. T. Islam, and M. R. Mita, IOSR J. Appl. Geol. Geophys. (IOSR-JAGG) 1(4), 47 (2013). https://doi.org/10.9790/0990-0144754

16. A. R. M. T. Islam and M. A. Habib, Int. J. Geophys. 2015, 840168 (2015). https://doi.org/10.1155/2015/840168

17. A. S. D. Ahmed and M. S. Islam, Int. J. Petrol. Geosci. Eng. 3, 41 (2015). 
18. M. M. Rahman, Master's thesis, Bangladesh University of Engineering \& Technology, Dhaka, Bangladesh (2015). http://lib.buet.ac.bd:8080/xmlui/bitstream/handle/123456789/3794/Full\%20Thesis.pdf?sequence=1

19. F. Y. Nipa and M. M. U. Monir, Int. J. Petrol. Geosci. Eng. 3, 25 (2015).

20. M. R. Islam, A. T. M. S. H. Muzemder, M. A. I. Khan and M. M. A. Hira, J. Petrol. Explor. Prod. Technol. 7, 569 (2017). https://doi.org/10.1007/s13202-016-0278-y

21. Daily Production Reports of Bangladesh Gas Fields Company Limited (BGFCL). https://www.bgfcl.org.bd/index.php/reports/daily-production-report Access on 11 October, 2017.

22. M. A. I. Khan, Production Forecasting of Rashidpur Gas Field Using Type Curve Analysis, preprint J. Eng. Sci. (2016). https://www.researchgate.net/publication/285917641_Production_Forecasting_of_Rashidpur_ Gas_Field_Using_Type_Curve_Analysis

23. Institute of Petroleum Engineering, Heriot-Watt University- Reservoir Simulation. https://www.scribd.com/doc/74468323/Heriot-Watt-University-Reservoir-Simulation

24. Schlumberger, Schlumberger Eclipse Reference Manual 2010.1 (given with the software).

25. M. B. Haq, Master's Thesis, Bangladesh University of Engineering \& Technology, Dhaka, Bangladesh, 2001.

26. M. I. Miah, Procedia Engineering (Elsevier) 90, 663 (2014). https://doi.org/10.1016/j.proeng.2014.11.789

27. A. T. Bourgoyne, K. K. Millheim, M. E. Chenevert, and F. S. Young, Applied Drilling Engineering (Society of Petroleum Engineers, Richardson, TX, 1986) pp. 289-291.

28. M. A. Islam, Master's Thesis, Norwegian University of Science And Technology, Norway, 2009.

29. S. Kumar, Gas Production Engineering (Gulf Publishing Company, Houston, Texas, 1987) 4.

30. S. M. S. Hoque, M. N. Mahmood, and T. U. Zaman - Proce. of the $3^{\text {rd }}$ Int. Conf. on Mechanical Industrial and Materials Engineering (Rajshahi, Bangladesh, 2017). http://icmime-ruet.ac.bd/2017/DIR/Contents/Technical\%20Papers/Related\% 20Technology/RT-57.pdf

31. $\mathrm{CO}_{2}$ Emission and Emission Rate (Metric Tons Per Capita) Bangladesh, 1994-2014 Year Data. https://data.worldbank.org/indicator/EN.ATM.CO2E.PC?end=2014\&locations=BD\&start=1994

32. Schlumberger Eclipse Software (version 2010.1).

33. Schlumberger Petrel Software (version 2013.1)

34. CK-12, Ocean-Continent Convergent Plate Boundaries, 2017. https://www.ck12.org/earth-science/Ocean-Continent-Convergent-Plate Boundaries/lesson/Ocean-Continent-Convergent-Plate-Boundaries-HS-ES/

35. Geology, Geomorphology and Seismotectonics of Bengal Basin with Special Emphasis on Kolkata and Its Adjoining Region. http://wbdmd.gov.in/writereaddata/chapter-2A.pdf 